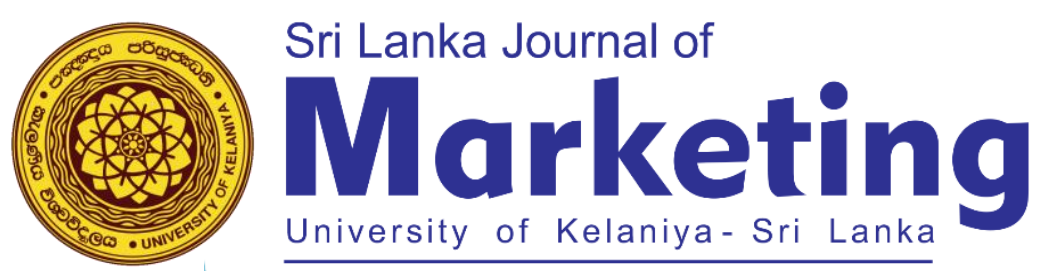

\title{
A Glance into the Life of Street Vendors in Sri Lanka: An Overview
}

\author{
Karunaratna A. C. \\ Faculty of Management and Finance, University of Ruhuna, Sri Lanka \\ acruhuna@gmail.com \\ Nathalia C Tjandra \\ The Business School, Edinburgh Napier University, Edinburgh, UK \\ n.tjandra@napier.ac.lk
}

\begin{abstract}
Street vendors play a vital role in the contemporary business context. However, considerable attention has not been paid to street vendors, and only a handful of studies have been conducted to evaluate the behaviour of street vendors. This study was conducted to analyze the key attributes of street vending in the context of Sri Lanka and the background of street vendors. The triangulation approach, involving qualitative and quantitative data collection methods, was adopted to conduct the study. Accordingly, qualitative tools such as in-depth interviews, observations and disguised customers were used in addition to the survey conducted. The background of street vendors was evaluated in terms of personal $\&$ family, educational, social \& cultural and economic aspects based on the data gathered from street vendors. Moreover, a few specific features were recognized in the context of street vending in Sri Lanka. As a major outcome of the study, a classification of street vendors was presented based on their behaviour, intention, functions and demographic variables.
\end{abstract}

Keywords: Informal Economy, Street Vending, Types of Street Vendors 


\section{INTRODUCTION}

Street vending, which has persisted for centuries, is recognized as an ancient and important type of livelihood (Bromley, 2000; Bhowmik \& Saha, 2012). Due to its critical role in the economy, Williams and Gurtoo (2012) identify street vending as an important profession and evaluate it as street entrepreneurship rather than street vending, while street vendors are termed street entrepreneurs. Street vendors have become a popular business category among the general public since they provide consumer goods at lower prices in convenient locations (Onyango et al., 2012). Accordingly, street vendors are a common sight that facilitates customers to purchase most of the goods to fulfil their dayto-day needs (Bhowmik, 2005; Rasanga \& Edirisinghe, 2014; Rathnayake, 2017).

The service rendered by street vendors is noteworthy. It can be seen that most street vendors provide the main source of income for their households (Rathnayake, 2017). However, the role of street vendors is generally not recognized and appreciated by the authorities, and their service is not accounted for national income due to the nature of the informality of their business activities (Recio \& Gomez, 2013). The exact numbers of street vendors are also not accounted for due to the high mobility of vendors even though millions of street vendors in developing countries in Asia, Africa and Latin America contribute to boosting the national economy to a greater extent.

Bhowmik and Saha (2012) declare that the life of street vendor is not comfortable since trading in pavements is full of uncertainties. Currently, street vending is not an easy type of business because they operate under a lot of constraints and barriers, and mostly criticized because of their nature of operations. For instance, criticism puts on the contestation of urban public spaces due to the activities of street vendors (Herath, 2015). The activities of street vendors have become a topical issue within the urban spaces of the developing world (Asiedu \& Agyei-Mensah, 2008). Generally, many street vendors operate in busy streets and considered a nuisance as they obstruct the people (Rathnayake, 2017). The living standard of street vendors is not stable, and they face many hardships and challenges. Sometimes, officials in municipal councils take some decisions on street vendors, like limiting street vending on some assigned places and streets due to some problems created by street vendors themselves. At the same time, the operations of street vendors are heavily influenced by different factors like seasons, festivals, politics and climate conditions etc. The sales and income also fluctuate accordingly. Therefore, street vendors' life is not a comfortable one. This is due to poor infrastructure facilities available and less attention of the authorities responsible for smoothly functioning their activities (Rathnayake, 2017).

The role of street vendors cannot be undervalued in the contemporary business context since they greatly contribute to fulfilling customer requirements. However, considerable attention has not been drawn to street vendors in recent decades, and only a handful of studies have been conducted in different 
countries. Meanwhile, little attention has drawn to street vendors in the Sri Lankan context as well (Rasanga \& Edirisinghe, 2014; Herath, 2015; Rathnayake, 2017). Therefore, this study was conducted to analyse the background of street vendors in terms of personal \& family, educational, social \& cultural and economic aspects, and evaluate the key features in the context of street vending in Sri Lanka.

\section{LITERATURE REVIEW}

Street vending, which is prevalent in almost all countries (Bhowmik, 2010), plays a vital role as a part of the informal business context in the economy (Recio \& Gomez, 2013; Crossa, 2014; Gamieldien \& Niekerk, 2017; Truong, 2017). Onyango et al. (2012) state that street vending is a type of informal business that provides alternative jobs to a large urban population who cannot get formal employment. According to Wongtada (2014), street vending provides an important source of earnings for the unemployed in urban areas while providing inexpensive goods at convenient locations for customers. The activities in the informal sector can be categorised into two sections, such as self-employed and casual labour. Accordingly, street vendors are recognized as an essential part of the informal sector (Bhowmik, 2005; Reid et al., 2010; Chauke et al., 2015). Moreover, street vendors are treated as selfemployed entrepreneurs (Yueh, 2009). According to Holy and Makhoane (2006), while street vending is recognized as a well-known occupation, street food vending is treated as one of the important segment in street vending. Rojas and Siga (2009) state that the self-employment and informality rates are considerably higher in developing countries than in industrialized countries.

According to Bhowmik (2005), street vendor is a person who offers goods for sale to the public without having a permanent built-up structure from which to sell, and they occupy space on the pavements of other public or private spaces, or they may play as mobile sellers by carrying their goods from place to place. Onyango et al. (2012, p. 108) define street vendors as "informal traders who sell goods or services outside of any enclosed premises or covered workplaces" Meanwhile, Wongtada (2014, p. 55) defines street vendors as "those entities selling goods and services in the street without having a permanent built-up structure." Street vending is treated as an income-generating activity where individuals sell their wares along streets and sidewalks to passing pedestrians and motorists (Onyango et al., 2012). Gamieldien and Niekerk (2017) declare that the role of street vendors is appreciated due to their reliable, convenient and competitive performance. Since street vendors sell consumption materials at lower prices compared to formal retail institutions, street vending has become popular among customers (Onyango et al., 2012).

In analysing reasons for selecting street vending, it can be identified that some street vendors tend to select it as a lifestyle due to the capacity to enjoy freedom and flexibility (Cross, 2000; Kayuni \& Tambulasi, 2009). Moreover, street vending has become popular and widespread as it requires little financial input and a low volume of skills (Onyango et al., 2012). Bhowmik and Saha (2012) state that 
the lack of gainful employment coupled with poverty and the lack of skills and education opportunities in rural areas push persons towards street vending. However, the lack of security in their livelihood and the lack of access to credit have become severe problems as curbs for smoothly functioning their business operations (Bhowmik, 2005).

Compared to the other countries in the region, the status of the street vendors in Sri Lanka is in a better position, and business activities are operated on the places like pavements of major roads, sides of streets and some assigned places as allocated by the authorities such as municipal councils (Bhowmik, 2005; Rathnayake, 2017). However, street vending is not an easy type of business as they operate under a lot of constraints and barriers. Moreover, their activities are mostly criticized because of their nature of operations. For instance, severe criticism puts on the contestation of urban public spaces due to the activities of street vendors (Herath, 2015). Some incidents are reported from time to time in national newspapers and social media about moving street vendors away from their locations by the authorities. This happens because street vendors do their operations illegally without having a license or use areas that are not allocated for such business activities, and those activities become a nuisance and create pedestrians traffic. Generally, many street vendors operate in busy streets and considered a nuisance as they obstruct the general public (Rathnayake, 2017). In such situations, the authorities, such as the officials in municipal councils, take some decisions on street vendors, like limiting street vending on some assigned places and streets.

Due to the substantial impact of street vending activities on society and the economy, some countries such as India (Anjaria, 2006; Bhowmik \& Saha, 2012; Bhuyan et al., 2020), the Philippines (Recio \& Gomez, 2013), Indonesia (Timothy \& Wall, 1997), South Africa (Holy \& Makhoane, 2006), Ghana (Asiedu \& Agyei-Mensah, 2008), Malawi (Kayuni \& Tambulasi, 2009), Kenya (Onyango et al., 2012) and Tanzania (Mramba et al., 2015) have studied some issues including the use of public space for street vending activities (Anjaria, 2006), the activities of street vendors (Asiedu \& Agyei-Mensah, 2008; Devlin, 2011; Roever \& Skinner, 2016), removal of street vendors from urban cities (Carrieri \& Murta, 2011), relocation of street vendors (Weng \& Kim, 2016), regulations and legal aspect of street vending (Austin, 1994; Bhowmik, 2010) and contribution of adolescent street vendors (Estrada, 2012). Accordingly, it can be noted that developing countries, especially in Asian and African regions, have drawn their attention to street vending since street vending has become a major category of the informal economy in developing countries compared to the developed countries. Moreover, it can be examined that street vending activities in developing countries are conventional and unregulated compared to the developed countries. However, the literature on street vending is not rich since less interest has drawn on street vendors and their activities. Truong (2017) also states that limited research considers the views of poor people, including street vendors, who constitute the informal economy. Moreover, scant attention has drawn to street vendors in the Sri Lankan context, while a handful of studies on street 
vendors are available (Herath, 2015; Rasanga \& Edirisinghe, 2014; Rathnayake, 2017). Therefore, this study is an endeavour to evaluate the key attributes of street vending in the context of Sri Lanka and the background of street vendors.

\section{MATERIALS AND METHODS}

The triangulation approach, involving both qualitative and quantitative data collection methods, was adopted to achieve the objectives of the study. In the first phase, a survey was conducted, and data were collected from 300 street vendors with the coverage of three provinces, namely Western, Southern and Sabaragamuwa. For data collection of the first phase, a structured questionnaire using both open-ended and close-ended questions was used. However, 07 out of 300 street vendors were removed due to the incompleteness of the questionnaire. In the second phase, it was targeted to employ in-depth interviews with 10 per cent of the previous sample to probe street vendors more open and reveal their background information in detail. Accordingly, 33 such in-depth interviews were held, which led to collecting more rich data with reference to different aspects of the background information of street vendors. More importantly, the observations and disguised customers as qualitative data collection tools were effectively used to observe and detect the nature of the behaviour of street vendors, which led to categorize street vendors based on their functionality and behaviour. Besides, a few authorities in local government were also interviewed to get their perceptions towards street vendors.

Table 01: Demographic Statistics of Respondents

\begin{tabular}{|c|c|c|c|c|}
\hline $\begin{array}{l}\text { Variable } \\
\text { Gender }\end{array}$ & No of Respondents & \multicolumn{3}{|c|}{ Percentage (\%) } \\
\hline Female & 128 & 43.69 & & \\
\hline Male & & & 165 & 56.31 \\
\hline \multicolumn{5}{|l|}{ Age Category } \\
\hline$<20$ & 01 & & 0.34 & \\
\hline $20-29$ & 33 & & 11.26 & \\
\hline $30-39$ & 64 & & 21.84 & \\
\hline $40-49$ & 88 & & 30.03 & \\
\hline $50-59$ & 61 & & 20.82 & \\
\hline $60-69$ & 41 & & 14.00 & \\
\hline$>70$ & 05 & & 1.71 & \\
\hline \multicolumn{5}{|l|}{ Civil Status } \\
\hline Single & 21 & 7.17 & & \\
\hline Married & 262 & & 89.42 & \\
\hline Divorced & 10 & 3.41 & & \\
\hline \multicolumn{5}{|l|}{ Level of Education } \\
\hline Primary & 40 & & 13.65 & \\
\hline Junior Secondary & 65 & & 22.18 & \\
\hline Senior Secondary & 158 & & 53.93 & \\
\hline Advanced Level & 30 & & 10.24 & \\
\hline
\end{tabular}


As depicted in Table 01, the sample consists of 128 female vendors and 165 male vendors. Accordingly, both male and female individuals engage in street vending. A few decades back, engaging in the business as well as employment was mainly headed by male, especially the father of the family as being the breadwinner in most of Asian countries. However, as a result of significant changes in the grounds of education, cultural, social and economic contexts during the last few decades; it has created many opportunities for female (Bruni et al., 2004; Khandker, 2005; Pitt et al., 2006; Ghouse et al., 2019). Moreover, the practice of integrity and justice as essential values and standards in the new society had a significant impact on the rights of female (Friedman, 2003; Tlaiss, 2015). Accordingly, female individuals, as same as male individuals, contribute to the economy with an equal contribution today.

The age of street vendors was classified into several groups as presented in Table 01 to identify which age categories are mainly involved in street vending. Accordingly, it can identify that different categories of ages as young, middle-aged and old individuals from the twenties to over seventies engage in this sort of informal business. Most of the street vendors represent the middle age category, for instance, from thirty to fifties. However, compared to the young and middle-aged street vendors, the category of elderly street vendors, (for instance, above sixty years old) is substantially high. As far as civil status is considered, many of them are married. Accordingly, around 90 per cent of street vendors in the sample are married. However, 10 female street vendors separated from their husbands were also recognised, and they have selected street vending due to lack of other options or alternatives for the livelihood. The majority of street vendors have obtained fairly good education due to the free education system in Sri Lanka, which will be further elaborated under the education background of street vendors. The gathered data will be analysed, and the results will be discussed in a broader sense in the next part of the article.

\section{DATA ANALYSIS}

The key findings of the study have been organised in several sections in order to follow a logical sequence in accordance of the objectives of the study. First, service and operational statistics will be presented. Next, the background of street vendors (personal \& family, educational, social \& cultural and economic which are referred as PESE) will be discussed. Then, the specific features identified in relation to the context of street vending in Sri Lanka will be outlined. Finally, the classification of street vendors based on their functionality and the nature of behaviour will be provided.

\section{THE NATURE OF OPERATIONS}

The main items sold by street vendors are fruits, vegetables, toys, apparel, porridge, fish, curd, cashew, ice cream, fruit juice, lunch packets, books, water bottles, pots, flowers, slippers, incense sticks, school items and lotteries etc. As per the observations of the research team, the quality of the items sold by 
street vendors ranges from low to average, even though some vendors mention that they sell highquality items. It was further observed that street vendors those sell items with low to average quality with affordable price have a good demand from customers. While a few street vendors serve as employees, the majority operate their own businesses. Many of them sell the same items, while onefourth of them sell different items from time to time based on the seasonal demands.

Table 02: Service and Operation Statistics

\begin{tabular}{|c|c|c|}
\hline Variable & No of Respondents & Percentage $(\%)$ \\
\hline \multicolumn{3}{|c|}{ Number of years of service } \\
\hline $1-2$ years & 25 & 8.53 \\
\hline $3-4$ years & 92 & 31.40 \\
\hline $5-9$ years & 102 & 34.81 \\
\hline 10 - 15 years & 54 & 18.43 \\
\hline 16 - 20 years & 13 & 4.44 \\
\hline $21-25$ years & 07 & 2.39 \\
\hline \multicolumn{3}{|c|}{ Number of hours served a day } \\
\hline 2 - 4 hours & 13 & 4.44 \\
\hline 5 - 7 hours & 49 & 16.72 \\
\hline 8 - 10 hours & 203 & 69.28 \\
\hline $11-15$ hours & 28 & 9.56 \\
\hline \multicolumn{3}{|c|}{ Accompanying partners for operations } \\
\hline Business partners & 04 & 1.37 \\
\hline Friends & 06 & 2.05 \\
\hline Family members & 110 & 37.54 \\
\hline Alone & 173 & 59.04 \\
\hline \multicolumn{3}{|l|}{ Family Support } \\
\hline Good support & 129 & 44.03 \\
\hline Less support & 102 & 34.81 \\
\hline No support & 62 & 21.16 \\
\hline \multicolumn{3}{|c|}{ Children's Assistance } \\
\hline Yes & 52 & 17.75 \\
\hline No & 241 & 82.25 \\
\hline
\end{tabular}

The number of street vendors has been increased during recent years due to the lack of employment opportunities. For instance, 219 (75 per cent) street vendors in the sample have entered into this business during the last 10 years and 117 (40 per cent) vendors out of them have entered during the last four years. Meanwhile, the number of street vendors who have engaged in this sort of business for more than 10 years is 74 (for instance, 25 per cent of the sample).

It was revealed that a considerable number of street vendors in the sample had practised this over a long period. For instance, it was found that around 20 respondents in the sample have engaged in street vending as their livelihood for more than 15 years, as illustrated in Table 02. Some vendors among them have served on the street for over 25 years. Now, it has become a part of their life. An old street vendor shared his experience as follows. 


\begin{tabular}{lcc}
\hline Statement & Age & Gender \\
\hline "I am on the street for more than 25 years now and I built my life being on the street. & \\
I have suffered many hardships but cannot give up street vending as it has become a & 62 & Male \\
part of my life." & & \\
\hline
\end{tabular}

\section{RESULTS AND DISCUSSION}

\subsection{Personal and Family Background}

More than half of the street vendors in the sample conduct the operations alone, while the others conduct the business activities with their family members, and only a few vendors are coupled with business partners and friends. Many of them are married, thus responsible for looking after the family and fulfilling the needs of the family members. There are young married couples with no children, but the majority have two or more children. The majority of street vendors receive good support from the spouse, while some of them (for instance, around 35 per cent in the sample) have less support from the spouse.

Moreover, children's assistance for street vending activities is at a minimum level, even below 20 per cent (Please refer to table 02). Many vendors mentioned that they do not encourage their children to involve in street vending since they do not intend their children to select street vending as their career. Instead, they dream of producing their children as well-educated individuals and finding suitable employment in the public or private sector. Thus, they are fully committed to providing a sound education to their children. However, this condition is somewhat different in other countries where children's involvement in street vending is very high (Estrada, 2012; Saxe, 1988; Ugochukwu et al., 2012). For instance, Estrada (2012) states that children and youth have become active contributors to their family in street vending businesses, especially children support in preparing food, assisting their parents with cash transactions and promoting their food to customers.

Many street vendors do not have a plan for their future, while they struggle with their current status due to many hardships, problems and challenges. The main target of many street vendors is survival. Truong (2017) also confirms this nature of the behaviour of street vendors in Vietnam and declares that most vendors do not have a specific plan for their future.

\subsection{Educational Background}

In Sri Lanka, the free education policy is implemented, and the government provides the necessary infrastructure. The education level was evaluated in terms of primary (Grade $1-5$ ), junior secondary (Grade 6 -9), senior secondary (Grade 10 - 11) and Advanced Level. Most of the street vendors who have obtained only primary education were recognized as elders over 50 years old. They mentioned that they were not much motivated towards education at the time of their schooling. Nevertheless, the 
majority of street vendors in the sample have gained senior secondary education. Meanwhile, 20 per cent of street vendors in the sample have passed the General Certificate of Education (Ordinary Level) examination. Moreover, 30 vendors (for instance, 10 per cent) have studied up to Advanced Level, while two of them have passed the General Certificate of Education (Advanced Level) examination but have been unable to find a suitable employment opportunity due to lack of opportunities.

Moreover, in-depth interviews were held with the two street vendors who have passed the General Certificate of Education (Advanced Level) examination. Both were really disappointed and mentioned that although they were seeking an employment opportunity from the government, they were unable to find an opportunity due to the lack of political support. They believe that only education, without political interference, will not be a qualification for an employment opportunity in the government sector. Thus, those two street vendors mentioned that this situation finally turned them towards street vending since there was no other alternative. They further added that they are very grateful to the education system because the knowledge gained has become immensely helpful to manage business activities.

\subsection{Social and Cultural Background}

In many cultures, a house is a very essential requirement and asset of a family, and every family attempts to build their dream house and invests more money to build it. For instance, Truong (2017) states that the size of the house reflects the wealth and success of the owner in Vietnamese culture. Therefore, street vendors in Vietnam attempt to utilize their income to build a house as a symbol of their success. Many street vendors involved in the study do not have a permanent shelter, which is considered a fundamental necessity in the Sri Lankan cultural and social context, and they live in rented houses or small temporary shelters with very basic amenities. Many families suffer from a lot of hardships, and there is at least a single child who is badly ill or disabled. Many female entrepreneurs revealed that they operate this business since some of their husbands are also disabled or seriously ill. It is noteworthy to mention that more than half of street vendors who contributed to this study have at least a single family member who is disabled or badly ill and suffered from these difficulties for a longer period of time. Thus, a considerable amount of their income spends on medicine.

The role of the ageing population as mature entrepreneurs has become a current trend (Singh, 2009). However, street vendors in their sixties and seventies in age have selected this sort of profession as they need to live independently and intend not to give any burden to their young children and their families. Most of these families do not have enough income to fulfil their needs. Therefore, the old individuals do not like to bother their children who are married and having their own families to look after. The selection of this street vending by elders provides strong evidence of the lack of a robust welfare system to look after senior citizens in the country. In many developed countries, the individuals in this age 
category may enjoy leisure and freedom (Pfau-Effinger, 2012; Dahl, 2018). Unfortunately, the welfare systems in most of the Asian and African countries are not in good condition, and senior citizens face many hardships when they are in the late stage in their lives (Usha \& Lalitha, 2016; Xiang et al., 2020). Accordingly, it can be observed that some senior citizens in the sixties and the seventies in age have also selected street vending to earn their living in Sri Lanka.

They are not well-organized, and not the members of any trade union or any society or club formulated. Accordingly, their bargaining power is fairly low. They lack awareness of the services provided by any government institutes and not registered in any databases either in government or non-government. The discussions with the authorities were also confirmed this non-availability of a structured database in relation to street vendors. Therefore, many of them have not received any type of training to enhance their knowledge, and neither marketing nor accounting practices are also followed due to the lack of knowledge.

Street vending is regarded as an essential service that performs to fulfil customer requirements, and many low to moderate-income customers purchase items from street vendors. However, street vendors believe that even though they provide an essential service for customers, street vendors are not wellrecognised in society, and their social acceptance is not so strong.

\subsection{Economic Background}

The level of income and the profit margin of street vendors will be mainly determined by the number of items sold on a particular day. They have flexible time schedules because of the nature of their business. Street vendors are required to take many efforts and a higher level of commitment in this context, and especially the number of hours spent on the street is very important. More than two-thirds (for instance, 203 respondents) of street vendors in the sample mentioned that they spend eight to ten hours on the street every day (Please refer to table 02). Meanwhile, 10 per cent of street vendors mentioned that they have to spend about 11 to 15 hours to obtain enough income, thus engage in street vending until late evening or night on some days. Meanwhile, street vendors who sell the items like porridge, curd, fish and lunch packets engage a few hours with a fair rate of return based on the demand.

While some street vendors earn healthy profits, many of them do not satisfy with their income. The majority mentioned that income is enough to fulfil their basic needs only. Accordingly, the main expenses of street vendors fall on food, clothing, sanitary and utilities. Due to the higher rate of inflation, most of their income goes on food. Meanwhile, the higher percentage of the income goes to education for their children for those families who are having children. Although the government provides free education, many parents have to pay for their children's tuition fee and purchase necessary educational materials. 
Enjoying leisure has become a very important part of life in this modern society. Therefore, many individuals spend money on entertaining opportunities. However, due to the inadequate level of income, street vendors have less opportunity for entertainment. Male vendors try to entertain their life mostly by having some alcohol, while they rarely go to a movie as a family. However, it was noted that female street vendors tend to save even a tiny percentage of their income for the future.

\subsection{Key Features of Street Vending in the Context of Sri Lanka}

Street vending in the context of Sri Lanka has its own specific features compared to other countries. Accordingly, the following key features were outlined based on the facts and figures gathered through different data collection tools including, survey, in-depth interviews and observations.

\subsubsection{Satisfactory Background of Education}

Many street vendors have a fairly good educational background. The majority of street vendors in the sample have gained secondary education. For instance, 20 per cent of street vendors in the sample have passed the General Certificate of Education (Ordinary Level) examination while another 10 per cent have studied up to Advanced Level.

\subsubsection{Female Engagement in Street Vending}

It was revealed that female engagement in street vending has increased during the last few years. For instance, around 44 per cent of the study sample is represented by female street vendors. Many of them have recently joined and selected street vending as an occupation due to high living costs, economic hardships and the lack of employment opportunities.

\subsubsection{Contribution of Senior citizens in street vending}

Some senior citizens in the sixties and the seventies in age have also selected street vending to earn their living. For instance, 15 per cent street vendors in the sample are above 60 years old.

\subsubsection{Children's involvement in street vending activities}

Children have become active contributors to their family involving in street vending activities in other Asian countries. However, it is quite low in the context of Sri Lanka, and street vendors do not motivate their children to engage in street vending activities. This is because they do not intend their children to select street vending as their career. 


\subsubsection{Depending on informal loans as the main source of financing}

The lack of financing has become a severe problem, and many of them have working capital issues since a considerable percentage of income goes to household consumption. Therefore, the main source of financing has become informal loans taken from a third party. There are money lenders who provide these informal personal loans with strict conditions and high-interest rate. Due to this nature of operations, street vendors earn a low-profit margin since the higher percentage of their income has to be paid as the interest of loans to those informal money lenders.

\subsubsection{Suffering from the lack of infrastructure}

Many street vendors have built temporary shelters, huts and stalls, and the rain and wind always destroy their temporary huts and stalls. The external forces such as climate changes, especially floods and droughts, make a severe issue and badly affect their operations.

\subsubsection{Unorganized nature of operations}

It can be seen that the players in many industries have formulated either a trade union or a club/society in order to increase their strength and bargaining power. Street vendors have not formulated such an association. Moreover, they have not registered in any government or non-government databases.

\subsubsection{Lack of knowledge and application of marketing and accounting practices}

Many of them are not aware of Accounting and Budgeting procedure, at least at the basic level. The majority of them do not possess the basic knowledge in Marketing and no concern towards customer care. These basic skills are worthwhile for evaluating the growth and progress of the business even though it is smaller in size.

\subsubsection{Lack of plan for the future}

Street vendors are not well-organized at the individual level or as a group. Many street vendors do not have a plan for their future. Most of them are not directed by a well-structured plan due to lack of knowledge of it and lack of motivation due to many challenges, problems and hardships encountered. Even though some have a growth-oriented motive, they do not have a good idea of achieving it.

\subsection{Types of Street Vendors}

There is no evidence in the scholarly literature in relation to the classification of street vendors. No particular research study has evaluated the types of street vendors and their nature of behaviour. Accordingly, this study contributes to the literature by presenting a classification of street vendors to fill this knowledge gap. Accordingly, different types of street vendors were recognized and classified 
based on the type of behaviour, intention, functions and demographic variables. Mainly, three sources such as interviews, observations and disguised customers were effectively used for data collection purpose to identify the below-mentioned types of street vendors. Consequently, ten pairs of street vendors were recognized as follows.

\subsubsection{Regular versus erratic street vendors}

The majority of vendors regularly conduct business activities in selecting this street vending as their main source of income and occupation, while others engage in street vending from time to time. Some individuals tend to do some other odd jobs but engage in street vending, especially in different seasons such as Christmas and New Year, for the purpose of earning a higher income within that particular period of time.

\subsubsection{Decent versus corrupted (honest versus deceitful) street vendors}

Some vendors engage in this business genuinely without harm to others, especially customers. They do not intend to cheat or exploit customers by selling defective or low-quality items. They always respect customers and attempt to fulfil their requirements. However, the observations discovered that some vendors always cheat innocent customers and exploit them by selling whatever they may sell, especially with defective and poor quality items.

\subsubsection{Cool versus aggressive street vendors}

There are vendors who do operations in a cooperative and friendly manner, not only with customers but also with competitors. They enjoy the business activities and satisfy with a fair rate of return. Although they encounter many hardships, they are not worried and ready to accept the challenges. They are very cooperative with competitors and help them when required. At the same time, the behaviour of some vendors which was observed tends to be aggressive. They always make disputes with associate vendors and compete with them. The neighbouring vendors criticise this type of behaviour since it destroys the image of street vendors in society.

\subsubsection{Growth-oriented versus survivals}

Some street vendors have an aspiration towards the growth of their business. A few among them have succeeded, while many have stuck due to various challenges and issues. The majority of street vendors struggle with the present condition and attempt to balance the income and consumption for survival in the business since the income is not sufficient to fulfil their needs due to the unstable economy and high living cost. 


\subsubsection{Independents versus politically motivated street vendors}

The majority of street vendors are independents and have selected this type of occupation to earn their livelihood. However, some street vendors are backed by politicians, and the opportunity has been provided by certain politicians based on their political agenda. These types of street vendors are more powerful than the general type of street vendors and always put pressure on other street vendors for their own benefits.

\subsubsection{Male Versus Female}

In general, male individuals mostly engage in street vending business. However, female vendors have selected this type of business by having taken the burden of the family on their shoulders due to different reasons like less family income and serious illnesses and disabilities of husband or children. Moreover, female engagement in business and entrepreneurship has been a dramatic increase during the last decade. Accordingly, the concept of female entrepreneurship as a separate category has been wellacknowledged.

\subsubsection{Young versus elders}

Most of the young individuals actively engage in street vending. However, those vendors who are above 60 years old (even above 70 years old) have a high tendency to engage in street vending since they are unable and unqualified to do any other type of occupation to earn their living. Many elderly individuals have become street vendors since they dislike becoming a burden to their children. Moreover, it was revealed that some elderly street vendors had selected this option as they were neglected by their children.

\subsubsection{Vendors who have a low level of income/profit versus a high level of income/profit}

A high percentage of street vendors fall into the low income/profit category. Therefore, it is necessary to address their needs and take the necessary actions to enhance the level of performance and living standards. Street vending does not mean a low-profit business at all the time. The proper location, along with high customer traffic, could help earn a high income and profit margin. Accordingly, street vendors who earn a considerable income/profit were also exposed in this study.

\subsubsection{Vendors Selling in a single location versus multiple locations}

Some street vendors have located in a particular place and conducting operations at that place over several years. Mostly, high customer traffic and convenience are the main factors that have been considered in selecting that location. Since they have a stable customer base, they are well-secured with 
a fair rate of return. Meanwhile, some other street vendors, especially young vendors, prefer to change the location and enjoy multiple locations searching for more customers.

\subsubsection{Vendors who sell the same item versus different items}

Some vendors tend to sell the same type of item/s such as either vegetable, fruits, porridge, curd and toys etc. However, there are some vendors who always tend to sell different items based on the seasonal demand to earn high income and profit.

\section{CONCLUDING REMARKS}

Street vendors play a vital role in the contemporary business context, where street vending has become one of the important categories in the informal business in the economy, especially by providing various types of product items to fulfil day-to-day customer needs. However, considerable attention has not been paid to street vendors in recent decades, and only a handful of studies have been conducted in different countries. Moreover, little attention has drawn to street vendors in the Sri Lankan context as well. Therefore, this study was conducted to analyse the key attributes of street vending in the context of Sri Lanka and the background of street vendors.

The triangulation approach, involving both qualitative and quantitative data collection methods, was adopted to achieve the objectives of the study. In the first phase, a survey was conducted, and different qualitative tools such as in-depth interviews, observations and disguised customers were used in the second phase of data collection. The background of street vendors was evaluated in terms of personal $\&$ family, educational, social \& cultural and economic aspects based on the data gathered from street vendors. Compared to the practices of street vending in some of the other countries, a few specific features were recognised in the context of Sri Lanka. More importantly, as an important contribution of the study, a classification of street vendors based on their behaviour, intention, functions and demographic variables, was presented. However, one of the major limitations of the study is the lack of focus on the income of street vendors since many street vendors were hesitant to discuss that matter. Moreover, it is difficult to have a precise estimate of the income of street vendors since their income may vary widely depending on the items sold, the number of hours operated, the location of the business conducted and business savvy etc. The future research direction lies in exploring the challenges faced by street vendors in continuation of street vending and how to empower street vendors for better performance and enhance their living standard.

\subsection{Funding}

This project was funded by British Council under the TRANSFORM education reform programme, which was established on the basis of the Memorandum of Understanding signed by the Ministry of 
Education and British Council. Currently, this programme works across secondary education, higher education and skills development in collaboration with the Ministry of Education, the Ministry of Higher Education, the University Grants Commission and the Ministry of Skills Development.

\subsection{Declaration of Conflict of Interest}

The authors declare no potential conflict of interest with respect to the research, authorship, and publication of this article.

\section{REFERENCES}

Anjaria, J. S. (2006). Street Hawkers and Public Space in Mumbai. Economic and Political Weekly, 41(21), 21402146. https://www.jstor.org/stable/4418270

Asiedu, A. B., \& Agyei-Mensah, S. (2008). Traders on the run: Activities of street vendors in the Accra Metropolitan Area, Ghana. Norwegian Journal of Geography, 62(3), 191-202. https://doi.org/10.1080/00291950802335806

Austin, R. (1994). “An Honest Living”: Street Vendors, Municipal Regulation, and the Black Public Sphere. The Yale Law Journal, 103(8), 2119-2131. https://doi.org/10.2307/797041

Bhowmik, S. K. (2005). Street Vendors in Asia: A Review. Economic and Political Weekly, 40(22), 2256-2264. http://dx.doi.org/10.2307/4416705

Bhowmik, S. K. (2010). Legal Protection for Street Vendors. Economic \& Political Weekly, 45(51), 12-15. https://www.jstor.org/stable/25764233

Bhowmik, S. K., \& Saha, D. (2012). Street Vending in Ten Cities in India. (Working Paper id:7018). School of Management and Labour Studies, Tata Institute of Social Sciences.

Bhuyan, B., Sahoo, B. K., \& Suar, D. (2020). Nutritional status, poverty, and relative deprivation among socioeconomic and gender groups in India: Is the growth inclusive? World Development Perspectives, 18, 100180. https://doi.org/10.1016/j.wdp.2020.100180

Bromley, R. (2000). Street vending and public policy: a global review. International Journal of Sociology and Social Policy, 20(1/2), 1-28. https://doi.org/10.1108/01443330010789052

Bruni, A., Gherardi, S., \& Poggio, B. (2004). Entrepreneur-mentality, gender and the study of women entrepreneurs. Journal of Organizational Change Management, 17(3), 256-268. https://doi.org/10.1108/09534810410538315

Carrieri, A. P., \& Murta, I. B. D. (2011). Cleaning up the City: A Study on the Removal of Street Vendors from Downtown Belo Horzonte, Brazil. Canadian Journal of Administrative Sciences, 28(2), 217-225. https://doi.org/10.1002/cjas.207

Chauke, P. K., Munzhelele, R., \& Maiwashe, A. (2015). Some factors impacting on street sellers' ability to generate above poverty line income in Vhembe District, South Africa: Logistic regression approach. Journal of Social Sciences, 44(1), 8-14. https://doi.org/10.1080/09718923.2015.11893452 
Cross, J. (2000). Street vendors, and postmodernity: conflict and compromise in the global economy. International Journal of Sociology and Social Policy, 20(1/2), 29-51. https://doi.org/10.1108/01443330010789061

Crossa, V. (2014). Reading for difference on the street: De-homogenising street vending in Mexico City. Urban Studies, 53(2), 287-301. https://doi.org/10.1177/0042098014563471

Dahl, N. (2018). Social inclusion of senior citizens in Japan: an investigation into the 'Community-based Integrated Care System'. Contemporary Japan, 30(1), 43-59. https://doi.org/10.1080/18692729.2018.1424069

Devlin, R. T. (2011). 'An area that governs itself': Informality, uncertainty and the management of street vending in New York City. Planning Theory, 10(1), 53-65. https://doi.org/10.1177/1473095210386070

Estrada, E. (2012). Changing household dynamics: Children's American generational resources in street vending markets. Childhood, 20(1), 51-65. https://doi.org/10.1177/0907568212458441

Friedman, E. J. (2003). Gendering the agenda: The impact of the transnational women's rights movement at the UN conferences of the 1990s. Women's Studies International Forum, 26(4), 313-331. https://doi.org/10.1016/S02775395(03)00077-3

Gamieldien, F., \& Niekerk, L. V. (2017). Street vending in South Africa: An entrepreneurial occupation. South African Journal of Occupational Therapy, 47(1), 24-29. http://dx.doi.org/10.17159/2310-3833/2017/vol47n1a5

Ghouse, S. M., McElwee, G., \& Durrah, O. (2019). Entrepreneurial success of cottage-based women entrepreneurs in Oman. International Journal of Entrepreneurial Behaviour \& Research,25(3), 480-498. https://doi.org/10.1108/IJEBR-10-2018-0691

Herath, H. M. W. (2015). A study of the concept of contested space in the context of street vending in Sri Lanka: A case study. [Master Thesis, University of Moratuwa]. http://dl.lib.mrt.ac.lk/handle/123/11394

Holy, A. V., \& Makhoane, F. M. (2006). Improving street food vending in South Africa: Achievements and lessons learned. International Journal of Food Microbiology, $111(2), \quad 89-92$. https://doi.org/10.1016/j.ijfoodmicro.2006.06.012

Kayuni, H. M., \& Tambulasi, R. I. C. (2009). Political Transitions and Vulnerability of Street Vending in Malawi. Theoretical and Empirical Researches in Urban Management, 4(3-12), 79-96. https://www.jstor.org/stable/24872439

Kerr, G. (2017). The motivations, business satisfaction and commitment of career and later-life older entrepreneurs. Journal of Small Business \& Entrepreneurship, 29(2), 140-155. https://doi.org/10.1080/08276331.2017.1288528

Khandker, S. R. (2005). Microfinance and poverty: Evidence using panel data from Bangladesh. The World Bank Economic Review, 19(2), 263-286. https://doi.org/10.1093/wber/lhi008

Mramba, N., Apiola, M., Sutinen, E., Haule, M., Klomsri, T., \& Msami, P. (2015, June 22-24). Empowering street vendors through technology: An explorative study in Dar es Salaam, Tanzania. IEEE International Conference on Engineering, Technology and Innovation/International Technology Management Conference, Belfast, UK. https://doi.org/10.1109/ICE.2015.7438651

Onyango, J. O., Olima, W. L. A., \& Onyango, L. (2012). Dynamics of Street Vending Phenomenon in the Kisumu Municipality, Kenya. International Journal of Arts and Commerce, 1(4), 107-120. https://repository.maseno.ac.ke/handle/123456789/3562 
Pfau-Effinger, B. (2012). Analyses of welfare-state reform policies towards long-term senior care in a cross-European perspective. European Journal of Ageing, 9(2). 151-154. https://doi.org/10.1007/s10433-012-0233-9

Pitt, M. M., Khandker, S. R., \& Cartwright, J. (2006). Empowering women with micro finance: Evidence from Bangladesh. Economic Development and Cultural Change, 54(4), 791-831. https://doi.org/10.1086/503580

Rasanga, R. A. C., \& Edirisinghe, J. (2014). Ordering the Disorderly: Public Perception on Re-Settlement of Street Vendors in Colombo. Sri Lankan Journal of Real Estate, 7, 18-33. http://dr.lib.sjp.ac.lk/handle/123456789/1584

Rathnayake, R. M. T. S. K. (2017, July 20). Striking a Balanced between Public Rights and Rights of Street Vendors: an Analysis of Street Vendors in Sri Lanka. APIIT Business, Law \& Technology Conference, 118-120. General Sir John Kotelawala Defence University.

Recio, R. B., \& Gomez, J. E. A., Jr. (2013). Street Vendors, their Contested Spaces, and the Policy Environment: A View from Caloocan, Metro Manila. Environment and Urbanization ASIA, 4(1), 173-190. https://doi.org/10.1177/0975425313477760

Reid, D. M., Fram, E. H., \& Guotai, C. (2010). A Study of Chinese Street Vendors: How They Operate. Journal of Asia-Pacific Business, 11(4), 244-257. https://doi.org/10.1080/10599231.2010.520640

Roever, S., \& Skinner, C. (2016). Street vendors and cities. Environment and Urbanization, 28(2), 359-374. https://doi.org/10.1177/0956247816653898

Rojas, G. V. M., \& Siga, L. (2009). On the nature of micro-entrepreneurship: evidence from Argentina, Applied Economics, 41(21), 2667-2680. https://doi.org/10.1080/00036840701335553

Saxe, G. B. (1988). The Mathematics of Child Street Vendors. Child Development, 59(5), 1415-1425. https://doi.org/10.2307/1130503

Singh, R. P. (2009). The aging population and mature entrepreneurs: Market trends and implications for entrepreneurship. New England Journal of Entrepreneurship, 12(1), 45-53. https://doi.org/10.1108/NEJE-12-012009-B004

Timothy, D. J., \& Wall, G. (1997). Selling to tourists: Indonesian street vendors. Annals of Tourism Research, 24(2), 322-340. https://doi.org/10.1016/S0160-7383(97)80004-7

Tlaiss, H. A. (2015). How Islamic business ethics impact women entrepreneurs: Insights from four Arab Middle Eastern countries. Journal of Business Ethics, 129(4), 859-877. https://doi.org/10.1007/s10551-014-2138-3

Truong, V. D. (2017). Tourism, poverty alleviation, and the informal economy: the street vendors of Hanoi, Vietnam. Tourism Recreation Research, 43(1), 52-67. https://doi.org/10.1080/02508281.2017.1370568

Ugochukwu, E. F., Okeke, K. N., Onubogu, C. U., \& Edokwe, E. S. (2012). Socio-demographic characteristics of child street vendors in Nnewi, Nigeria. Nigerian Journal of Paediatrics,39(4), 174-178. https://doi.org/10.4314/njp.v39i4.5

Usha, V. K., \& Lalitha, K. (2016). Quality of life of senior citizens: A rural-urban comparison. Indian Journal of Social Psychiatry, 32(2), 158-163. https://doi.org/10.4103/0971-9962.181104

Weng, C. Y., \& Kim, A. M. (2016). The Critical Role of Street Vendor Organizations in Relocating Street Vendors Into Public Markets: The Case of Hsinchu City, Taiwan. Journal of Policy Development and Research, 18(1), 4770. https://www.jstor.org/stable/26328240 
Williams, C. C., \& Gurtoo, A. (2012). Evaluating competing theories of street entrepreneurship: some lessons from a study of street vendors in Bangalore, India. International Entrepreneurship and Management Journal, 8, 391409. https://doi.org/10.1007/s11365-012-0227-2

Wongtada, N. (2014). Street Vending Phenomena: A Literature Review and Research Agenda. Thunderbird International Business Review, 56(1), 55-75. https://doi.org/10.1002/tie.21596

Xiang, L., Yu, A. T. W., Tan, Y., Shan, X., \& Shen, Q. (2020). Senior citizens' requirements of services provided by community-based care facilities: a China study. Facilities, 38(1/2), 52-71. https://doi.org/10.1108/F-02-20190023

Yueh, L. (2009). China's Entrepreneurs. World Development, 37(4), $778-786$. https://doi.org/10.1016/j.worlddev.2008.07.010 